University of Texas Rio Grande Valley

ScholarWorks @ UTRGV

$12-2014$

\title{
Differential response by bronzed cowbirds to songs of potential hosts in the lower Rio Grande Valley of Texas
}

Mary J. Janecka

Timothy Brush

The University of Texas Rio Grande Valley

Follow this and additional works at: https://scholarworks.utrgv.edu/bio_fac

Part of the Biology Commons

\section{Recommended Citation}

Mary J. Janecka and Timothy Brush "Differential response by bronzed cowbirds to songs of potential hosts in the lower Rio Grande Valley of Texas," The Southwestern Naturalist 59(4), 556-561, (1 December 2014). https://doi.org/10.1894/EKL-03.1

This Article is brought to you for free and open access by the College of Sciences at ScholarWorks @ UTRGV. It has been accepted for inclusion in Biology Faculty Publications and Presentations by an authorized administrator of ScholarWorks@ UTRGV. For more information, please contact justin.white@utrgv.edu,william.flores01@utrgv.edu. 


\title{
DIFFERENTIAL RESPONSE BY BRONZED COWBIRDS TO SONGS OF POTENTIAL HOSTS IN THE LOWER RIO GRANDE VALLEY OF TEXAS
}

\author{
Mary J. Janecka AND Timothy BRush*
}

\author{
Department of Biology, University of Texas-Pan American, 1201 W. University Drive, Edinburg, TX 78539 \\ Present address of MJJ: Department of Biology, Texas A EMM University, 3258 TAMU, College Station, TX 77843-3258 \\ *Correspondent: tbrush@utpa.edu
}

\begin{abstract}
How bronzed cowbirds (Molothrus aeneus) find nests to parasitize is poorly known, especially whether they use host vocalizations as sources of information about nest location and status. We conducted 120 point-count surveys, followed by broadcasts of host songs, at Santa Ana National Wildlife Refuge in the Lower Rio Grande Valley of Texas in 2008 and 2009. Bronzed cowbirds responded to songs of potential host species by flying toward the source of the playback as single females or males or multiple females and males. Bronzed cowbirds responded in greater numbers to the songs of oriole species (Icterus) than to olive sparrow (Arremonops rufivirgatus), a lower-quality host species. Such responses by bronzed cowbirds could facilitate the location of host nests for nests of species difficult to find or to look into.

RESUMEN-Es poco conocido como el tordo ojirrojo (Molothrus aeneus) encuentra nidos para parasitar, especialmente si utiliza vocalizaciones de los huéspedes como fuentes de información acerca de la ubicación y el estatus de nidos. Llevamos a cabo 120 muestreos de puntos-conteo seguidos de emisiones de canciones de huéspedes en el Santa Ana National Wildlife Refuge en el valle bajo del rio Grande de Texas en 2008 y 2009. Los tordos ojirrojos respondieron a las canciones de especies de huéspedes potenciales, volando hacia el lugar donde las canciones eran emitidas. Las respuestas fueron registradas en machos y hembras individualmente, así como en machos y hembras combinados. Los tordos ojirrojos exhibieron una respuesta mayor a las canciones de especies de calandrias (Icterus) que a las canciones del gorrión oliváceo (Arremonops rufivirgatus), que es una calidad menor de huésped. Tales respuestas por los tordos ojirrojos podrían facilitar la localización de nidos de especies cuyos nidos son difíciles de encontrar o examinar.
\end{abstract}

Interspecific brood parasitism, a form of social parasitism, is a behavior in which the female of one species deposits her eggs in the nest of another species. If the egg is accepted, this behavior shifts the cost of rearing offspring to another species (Rothstein, 1990; Sealy, 1996). In the Lower Rio Grande Valley (LRGV) of southern Texas, the 54-g bronzed cowbird (Molothrus aeneus) greatly outnumbers the 36-g brown-headed cowbird (Molothrus ater; Gehlbach, 1987; Brush, 2005). Bronzed cowbirds are generalist brood parasites, with 101 species victimized, and 44 species documented raising cowbird young, despite limited and uneven research coverage throughout the species' range (Friedmann, 1929; Carter, 1986; Sealy et al., 1997; Ellison and Lowther, 2009).

Cowbird host suitability is dependent on several factors, including overlapping breeding seasons, acceptance of cowbird eggs, and nest accessibility to laying female cowbirds (Sealy et al., 2002). Additionally, suitable cowbird hosts must provide a protein-rich diet to juvenile cowbirds and be relatively safe from predation, a major cause of nestling loss in both cowbird species (Carter, 1986; Sealy et al., 2002). Ellison and Sealy (2007) recorded direct loss of bronzed cowbird eggs due to host defense by orioles during attempted laying. Many bird species attempt to conceal their nests to avoid both brood-parasitism and nest depredation. Thus, strategies that allow cowbird females to locate nests of the most suitable hosts should be favored, so that eggs can be laid quickly and safely (Peer and Sealy, 1997; Strausberger, 1998).

Two hypotheses have been proposed to describe how cowbirds are thought to locate nests. 1) In active nest searching (Thompson and Gottfried, 1981): female brown-headed cowbirds systematically move through habitats both as individuals and groups, presumably for the purpose of nest location (Clotfelter, 1998). Additionally, flushing behavior has been described in brownheaded cowbirds-females make several short flights in dense vegetation, landing abruptly with loud wing flaps and then watching for the movements of the birds flushed from the nests (Smith, 1912; Norman and Robertson, 1975). 2) Using host activity to find nests: in which females rely on host cues such as vocalization or nest building for laying decisions, either to find the nest initially or to determine the appropriate laying time 


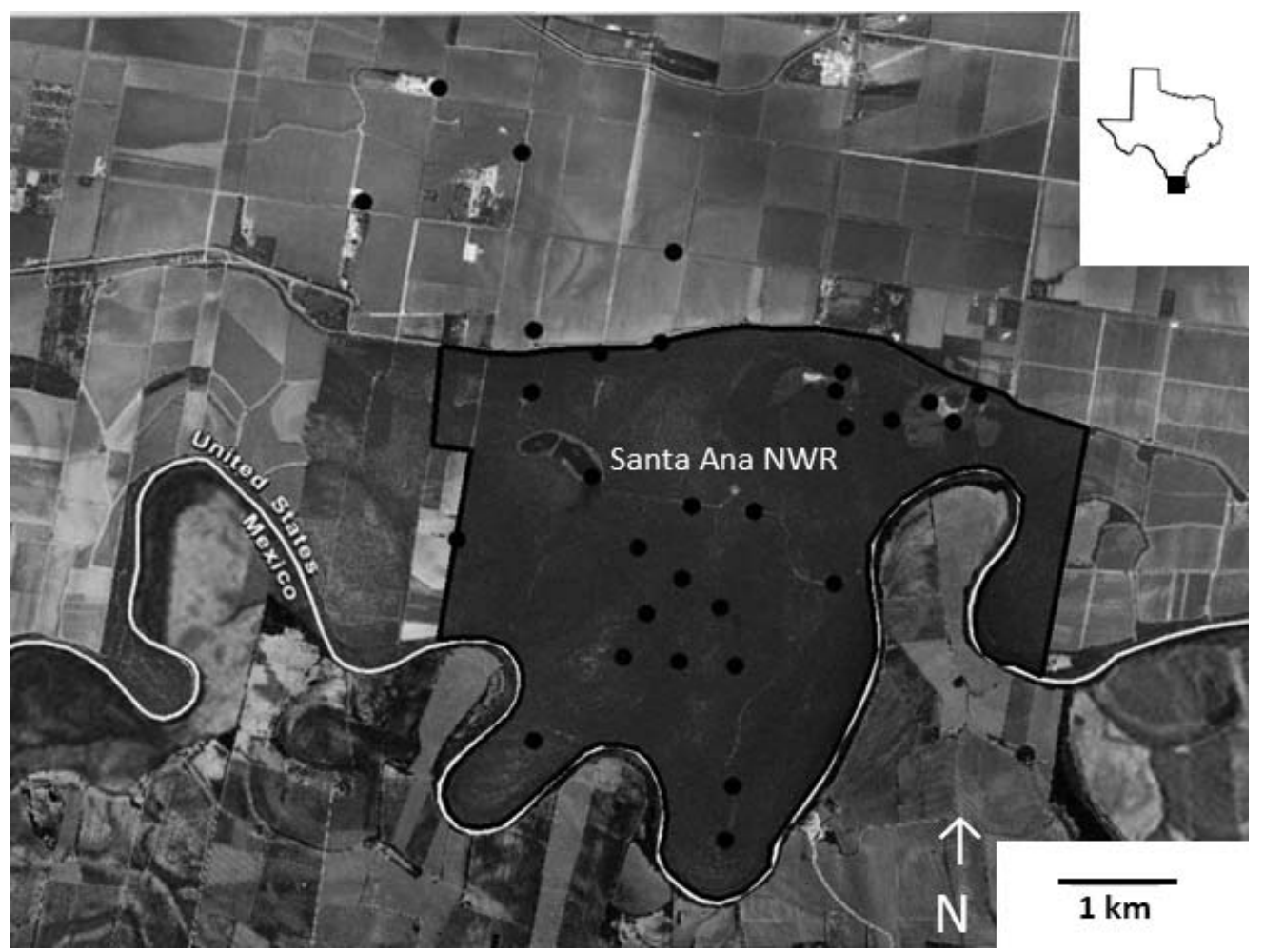

Fig. 1.-Map of Santa Ana National Wildlife Refuge, Hidalgo County, Texas, showing locations at which point counts were done and host songs were broadcast. Points were located within the refuge boundaries (outlined in black) and in surrounding agricultural fields. Inset shows location of Hidalgo County, Texas.

(Grieef and Sealy, 2000; Banks and Martin, 2001). This hypothesis predicts that it would be advantageous for female cowbirds to be able distinguish between heterospecific vocalizations, to preferentially parasitize more suitable hosts (those accepting cowbird eggs and regularly raising cowbird offspring), and to avoid species that are highly aggressive, likely to reject cowbird eggs (Hauber et al., 2002), or are unsuitable hosts because of their small size or high nest depredation rates (Brush, 2005).

Hauber et al. (2002) demonstrated that brown-headed cowbirds had a differential physiological response to playbacks of different host species vocalizations, indicating that this species is able to distinguish between heterospecific songs. There was, however, no behavioral response either in the lab or the field setting to playbacks, as brown-headed cowbirds were not attracted to playback of host vocalizations in the field unless conspecific chatter was played before the host species vocalizations. Bronzed cowbirds, on which little research has been done, could rely partially on host vocalizations to find nests. Monk and Brush (2007) found that bronzed cowbirds responded to playback of Audubon's oriole (Icterus graduacauda) song, which was used in oriole surveys in the western LRGV. Monk and Brush (2007) suggested additional studies, using playback songs of additional species, to further study this apparent nest-locating behavior. We tested some predictions of the host activity hypothesis for the bronzed cowbird at Santa Ana National Wildlife Refuge
(Santa Ana NWR). We predicted that bronzed cowbirds would 1) be attracted by the recorded playback of host species songs, and 2) that there would be a differential response to songs on the basis of host suitability and current abundance.

Methods-Study Area and Host Species-MJJ conducted point-count surveys and host-song broadcasting in May and June of 2008 and 2009 at Santa Ana NWR and adjacent agricultural areas (Fig. 1). Santa Ana NWR is an 842-ha tract of mature wooded habitat on the north bank of the Rio Grande in southern Hidalgo County. The refuge is mainly thorn forest, riparian forest, and open wetlands (Carter, 1986), with surrounding agricultural land mainly in sorghum, cotton, and winter vegetables.

Four known host species were selected on the basis of their historic and current abundance within the refuges, severity of parasitism by bronzed cowbirds, and ability to fledge parasitic offspring (Friedmann, 1929; Carter, 1986; Brush, 2005). Altamira oriole (Icterus gularis; $67 \mathrm{~g}$ ) began nesting at Santa Ana NWR by the early 1960s and is currently an uncommon breeder throughout the refuge (Gehlbach, 1987; Brush, 2005). Altamira orioles defend their conspicuous nests against cowbird entry, have been documented removing cowbird eggs, and early data suggested that they could almost completely prevent parasitism by bronzed cowbirds (Friedmann and Kiff, 1985; Sealy and Underwood, 2004). However, they sometimes accept cowbird eggs and have been documented raising bronzed cowbird fledglings in 5-8\% of active nests in the LRGV (Hathcock and Brush, 2004; Werner et al., 2007). 
Audubon's oriole (46 g) has been less intensively studied than other orioles, but was formerly heavily parasitized by bronzed cowbirds throughout the LRGV (Friedmann, 1929). This oriole, once fairly common at Santa Ana NWR, was very rare there by the early 1970s (Gehlbach, 1987) and disappeared from Santa Ana NWR by 1980. Audubon's oriole remains a fairly common breeder $70 \mathrm{~km}$ west and $90 \mathrm{~km}$ north of Santa Ana NWR and is still parasitized, often successfully, by bronzed cowbirds (Brush, 2005; Monk and Brush, 2007).

Hooded oriole (Icterus cucullatus; $25 \mathrm{~g}$ ) was once a very common breeder in the LRGV, with a breeding population of ca. 400 pairs at Santa Ana NWR in the 1940s. Heavily parasitized by bronzed and brown-headed cowbirds, hooded orioles declined at Santa Ana NWR in the 1950s and 1960s and were extirpated by 1973 (Gehlbach, 1987). Since the 1990s, the species has bred in very low densities in urban and rural habitats across the LRGV, including the northern boundary of Santa Ana NWR (Brush, 2005).

Olive sparrow (Arremonops rufivirgatus; $24 \mathrm{~g}$ ), a very common breeder at Santa Ana NWR and across the LRGV, is heavily parasitized by bronzed cowbirds but has high nest depredation rates (Carter, 1986; Hathcock, 2000). Olive sparrow is probably a low-quality host, given high nest depredation and its much smaller size than most bronzed cowbird hosts (Carter, 1986; Chace, 2004).

All species we studied build well-concealed nests, except for Altamira oriole, which builds long, hanging nests at edges of woodlands in highly conspicuous locations (Brush, 2005). Ellison et al. (2006) reported that bronzed cowbirds targeted hooded and orchard (Icterus spurius) orioles almost exclusively in south-central Texas, where these species were common. Carter (1986) found bronzed cowbirds parasitizing a wide variety of species, with no evidence of preferential host use, at Santa Ana NWR.

Twice during each breeding season (May and June 2008 and 2009), MJJ conducted early-morning, fixed-radius point-count surveys at each point. On the basis of vegetative and avian community observation at Santa Ana NWR, four habitat types were included within the study area: riparian forest, thorn forest, open wetlands, and agricultural fields with two replicates per type (Carter, 1986). Five points were located within each habitat replicate using stratified random sampling methodology to include all habitat types (Fig. 1; Hutto et al., 1986). Any point located within $200 \mathrm{~m}$ of another point was relocated to avoid repeated counts of individuals (Hutto et al., 1986).

Surveys were conducted from sunrise to $1030 \mathrm{~h}$ Central Daylight Time, or until weather conditions changed. Prohibitive weather included winds exceeding approximately $4.5 \mathrm{~m} / \mathrm{s}$, temperatures above $32^{\circ} \mathrm{C}$, or precipitation. Points were accessed on foot. Each point count consisted of an initial 10-min observation period, during which the number and sex of bronzed cowbirds were recorded, as well as their distance from the point. Cowbirds were identified by sight or song, and sex was determined through a combination of both, as females have sexspecific calls (Ellison and Lowther, 2009). It was not possible, in typical field conditions, to determine age of males or females. During the initial observation, all cowbirds were identified within $0-25,25-50$, and $50-100 \mathrm{~m}$ by sight and sound and recorded in the order in which they were observed for analysis (Hutto et al., 1986). Birds that were located outside the pointcount radius initially but moved into the radius during the 10- min observation period were included in the analysis. Also, individuals that were flushed on approach to the center of the point were included as being within the point-count radius and their distance from the center was estimated.

Broadcast of Host Species Vocalization-After the initial counting period at each point, a randomly selected host song was broadcast, followed by an additional $3 \mathrm{~min}$ of observation to allow bronzed cowbirds to respond. The recording of the host species' song was played three times (approximately $2 \mathrm{~min}$ in length) using recorded songs from Bird Songs of the Lower Rio Grande Valley and Southwestern Texas (Keller, 2000) and a Radio Shack CTR-121 tape recorder. The volume of the recording was constant at each site and set to simulate the volume of an actual song heard in the field. A response by bronzed cowbirds to the playback, such as vocalizations or by flying close to the speakers, was recorded during the 3-min period subsequent to the playback. A cowbird was considered to respond if it flew within $10 \mathrm{~m}$ of the tape recorder. Individuals already located within $10 \mathrm{~m}$ of the tape recorder were not included in the analysis unless they alighted within $2 \mathrm{~m}$ of the tape recorder, indicating an active response. Cowbird response was categorized on the basis of the number of birds responding and the sex of the individuals involved. Responses by other species, including brown-headed cowbirds or host species within the area, were also documented. Additional data were collected with regard to perch use and the activities of cowbirds observed during the initial point count.

Statistical Analysis - The results of this survey were analyzed using SPSS Statistical Software 17.0 with $\alpha<0.05$ (SPSS Inc., 2007). Because of the small sample sizes, nonparametric tests were used to detect differences among and between groups. For response to the playbacks of host vocalizations, the Friedman test was used to detect significant differences in abundance before and after the broadcasts. A Wilcoxon test was used to detect differences in response between host species. A chisquare analysis was used to detect difference in the frequency of bronzed cowbird response types.

REsults-Overall, bronzed cowbirds responded to broadcast host songs in $34 \%$ of the 120 broadcast songs at Santa Ana NWR. In all positive instances, bronzed cowbird responses occurred during the actual broadcast of the host song or within $10 \mathrm{~s}$ of the end of the recording. No response was initiated after the 10 -s period immediately after the end of the playback; nonetheless the 3-min observation period was maintained for all point-count surveys.

There was an average response of $1.39 \pm 1.57 \mathrm{SD}$ cowbirds per count. Of the 41 responses, hooded oriole song was responsible for $39 \%$, Altamira oriole song $36 \%$, Audubon's oriole song $19 \%$, and olive sparrow song $4 \%$. There were significant differences in the number of cowbirds recorded at the census points before and after the playback of the host vocalizations, indicating that bronzed cowbirds did respond to host vocalizations (Wilcoxon $Z=5.01, P<0.01$ ). There was also a significant difference in the number of responses to various host species songs (Friedman $\chi^{2}=92.66, d f=2, P$ $<0.001$ ), indicating that there was a differential response among species. Bronzed cowbirds were not observed to 
approach the tape recorder before the playback of any song for any of the point counts.

Response behaviors of bronzed cowbirds varied. There was a significant difference in the frequency at which the various responses occurred, with a single male responding less frequently than single females, groups of females, or females accompanied by a male $\left(\chi^{2}=17.07, d f=3, P=\right.$ 0.01 ). The most common response type, occurring in $46.1 \%$ of the observations, involved a single female flying silently into the vicinity $(<10 \mathrm{~m})$ of the tree in which the tape recorder was located. The female would approach the area either by flying in over the canopy and alighting on a perch in the upper portion of a tree near where the tape recorder was located or by hopping through the midstory vegetation and maintaining a mid-story location in the vicinity of the tape player. Once there, she would observe the surrounding area. After a period of 5-26 s, the female would leave the area by flying over the canopy of the habitat.

The second most common response involved a single female or group of females accompanied by a male or males, occurring $24.4 \%$ of the time. The females would arrive in the area first, followed almost immediately by the male(s). The male(s) would alight in the same tree as the females and then perform the bow-and-hover displays characteristic of the bronzed cowbird courtship display. Both the bow-and-hover displays were performed perched in a tree and were directed at the nearest female. Females terminated the courtship bout by flying out of the area 5$14 \mathrm{~s}$ after it was initiated. Both the females and the male would follow the first female cowbird to leave the area.

The third most common response, occurring in $20.9 \%$ of the observations, involved groups of two to five females unaccompanied by a male. These groups approached the area in a similar manner as individual females, although they tended to remain in the area longer, ranging from 7 to $36 \mathrm{~s}$, during which time they would alight on several different branches. Neither individuals nor groups of females were heard vocalizing during these responses.

On a few occasions ( $7.6 \%$ of the observations) responses consisted of a single male. These responses occurred primarily in the wetland and agricultural habitats. Males would approach the area flying well over the habitat, alight on a snag, tree, or power line near the tape recorder, and proceed to sing. Two of the three males remained to vocalize in the area for the full 3-min observation period, whereas one left the area and flew out of sight after a single vocalization, closely followed by two male red-winged blackbirds (Agelaius phoeniceus).

Other species also responded to the playback of the host vocalizations. Olive sparrows on three occasions responded to playbacks of olive sparrow song when bronzed cowbirds did not; all of these occurred in thorn forest habitat. A single adult Altamira oriole also flew into the vicinity of the tape player that played Altamira oriole song in riparian habitat, alighted for less than $2 \mathrm{~s}$, and flew out of sight. Also, a single brown-headed cowbird female responded to the recording of an olive sparrow in thorn forest habitat by approaching the tape player directly, briefly landing on it with wings still outstretched, and then flying out of sight.

Discussion-The results of this analysis are generally consistent with the predictions of the host activity hypothesis in showing that bronzed cowbirds did respond to broadcast host songs. A differential behavioral response between species indicates that bronzed cowbirds differentiated between songs of different host species. Bronzed cowbirds responded more frequently to songs of the three oriole species than to songs of the olive sparrow. Although all species are known to raise bronzed cowbirds successfully, olive sparrows are probably less suitable for and attractive to bronzed cowbirds because of their higher nest depredation rates and possibly lower ability to raise bronzed cowbird fledglings (Goguen et al., 2011). Also, since olive sparrows are the most common bronzed cowbird host at Santa Ana NWR and occur throughout the refuge, bronzed cowbirds may find olive sparrow nests relatively easily by actively searching through the habitat for olive sparrow pairs.

It is interesting that bronzed cowbirds responded frequently to Altamira oriole songs, since Altamira orioles resist brood parasitism and seldom raise bronzed cowbirds (Hathcock, 2000; Werner et al., 2007). However, the relatively low nest depredation rates on Altamira oriole nests and the large size of the orioles, making them better hosts for bronzed cowbirds, may create a strong selective pressure for bronzed cowbirds to seek out Altamira oriole nests. The large hanging nests of Altamira orioles are very conspicuous but difficult to see into, so song may attract cowbirds by indicating that the nest is active and worth investigating. The dynamics of attempted parasitism, frequency of ejection, and impacts on host nesting success in this species pair deserve further study.

Audubon's and hooded orioles, given their current absence or scarcity at Santa Ana NWR, would represent rare but valuable resources, so it might pay cowbirds to seek out singing males to help focus searches for these highly suitable hosts that build inconspicuous nests. Given that hooded orioles still nest along one edge of Santa Ana NWR and in low numbers throughout the LRGV, bronzed cowbirds might still be exposed to hooded oriole song, and some could have been raised by hooded orioles (Brush 2000). However, it is somewhat surprising that bronzed cowbirds responded to songs of Audubon's oriole, given that species' absence from Santa Ana NWR for at least 30 years. We speculate that dispersal of bronzed cowbirds brings experienced birds from the current Audubon's oriole range, $70-90 \mathrm{~km}$ west and north of Santa Ana NWR. Bronzed cowbirds may preferentially parasitize the hosts by which they themselves were raised (Payne et al., 2000; Ellison et al., 2006; 
Marsico and Reboreda, 2008) or may be responding to general song types.

The fact that response to olive sparrow songs was so low suggests that cowbirds are not just responding to song in general. Limited song playbacks in 2009 at Laguna Atascosa National Wildlife Refuge, $70 \mathrm{~km}$ east of Santa Ana NWR, found that bronzed cowbirds responded to songs of several oriole species and to a more limited extent, the songs of the long-billed thrasher (Toxostoma longirostre), green jay (Cyanocorax yncas), and northern cardinal (Cardinalis cardinalis), all known host species, but not at all to songs of olive sparrows or Couch's kingbirds (Tyrannus couchii; Gorton, 2010). Couch's kingbird is an active nest defender and egg ejector (Carter, 1986), although it has rarely raised fledgling cowbirds (Clotfelter and Brush, 1995). This suggests that bronzed cowbirds were responding to potential hosts rather than any disturbance caused by the playback itself.

Strausberger and Ashley (2003) and Ellison al. (2006), using molecular markers, determined that individual brown-headed and bronzed cowbirds, respectively, act as generalists in a given season. Host choice and parasitism intensity by bronzed cowbirds vary widely. For example, long-billed thrashers were heavily parasitized at Santa Ana NWR in 1980 and 1981 (Carter, 1986), but no nests were parasitized at a study site ca. $230 \mathrm{~km}$ north of Santa Ana NWR in 1977 and 1978 (Fischer, 1980). Although bronzed cowbirds were present at both sites, Santa Ana NWR may experience higher parasitism pressure, given its "island in a sea of agriculture" status. Thus, it would pay individual bronzed cowbirds to distinguish between songs of a variety of species, if competition for hosts is sometimes intense.

On the basis of our results, it appears that host selection behavior in bronzed cowbirds is triggered at least in part by host activity, namely male songs. Our response data experimentally replicate Carter's (1986) observation that females search for nests individually or in small groups. Male bronzed cowbirds, which would not be seeking nests to lay eggs in, may be able to obtain more copulations by keying in on a cue that females are likely to respond to, or by just following females (Clotfelter, 1995; Manolis and Cruz, 2002). Although we did not observe copulation in this study, the fact that males often displayed to females in such situations supports this hypothesis. Future research might profitably focus on bronzed cowbird responsiveness to songs of species outside the current range of bronzed cowbirds as well as nonhost oriole-like songs, to investigate the role of learning or innate responsiveness (Carter, 1986) of bronzed cowbirds. Additionally, it would be important to determine if these responses to host song result in a higher probability of female cowbirds finding nests in which to lay their eggs.

We thank the staff of Santa Ana NWR for their support of this research and for allowing us access to the refuge. We are grateful to R. Edwards, B. Fredensborg, H. Deyoe, P. Lowther, and Z. Faulkes for their constructive criticism of earlier versions of this manuscript. Funding was provided to MJJ by the Ruth and Katherine Dugger Fund.

\section{Literature Cited}

Banks, A. J., AND T. E. Martin. 2001. Host activity and the risk of nest parasitism by Brown-headed Cowbirds. Behavioral Ecology 12:31-40.

Brush, T. 2000. Bronzed Cowbirds (Molothrus aeneus) still parasitize Hooded Orioles (Icterus cucullatus) in the Lower Rio Grande Valley of Texas. Bulletin of the Texas Ornithological Society 33:9-10.

BRush, T. 2005. Nesting birds of a tropical frontier; the Lower Rio Grande Valley of Texas. Texas A\&M University Press, College Station, Texas.

Carter, M. D. 1986. The parasitic behavior of the Bronzed Cowbird in south Texas. Condor 88:11-25.

CHACE, J. F. 2004. Habitat selection by sympatric brood parasites in southeastern Arizona: the influence of landscape, vegetation, and species richness. Southwestern Naturalist 49:24-32.

Clotfelter, E. D. 1995. Courtship display and intrasexual competition in Bronzed Cowbirds. Condor 97:816-818.

Clotfelter, E. D. 1998. What cues do Brown-headed Cowbirds use to locate Red-winged Blackbird host nests? Animal Behavior 55:1181-1189.

Clotfelter, E. D., and T. Brush. 1995. Unusual parasitism by the Bronzed Cowbird. Condor 97:814-815.

Ellison, K. AND P. E. Lowther. 2009. Bronzed Cowbird (Molothrus aeneus) in The birds of North America Online (A. Poole, editor). Cornell Lab of Ornithology, Ithaca, New York. Birds of North America Online: <http://bna.birds.cornell.edu. bnaproxy.birds.cornell.edu/bna/species/144>. Accessed 27 July 2012.

Ellison, K., and S. G. Sealy. 2007. Small hosts infrequently disrupt laying by Brown-headed Cowbirds and Bronzed Cowbirds. Journal of Field Ornithology 78:379-389.

Ellison, K., S. G. Sealy, and H. L. Gibbs. 2006. Genetic elucidation of host use by individual sympatric Bronzed Cowbirds (Molothrus aeneus) and Brown-headed Cowbirds ( $M$. ater). Canadian Journal of Zoology 84:1269-1289.

Fischer, D. H. 1980. Breeding biology of Curve-billed Thrashers and Long-billed Thrashers in southern Texas. Condor 82:392-397.

Friedmann, H. 1929. The cowbirds: a study in the biology of a social parasite. CC Thomas, Springfield, Illinois.

Friedmann, H., ANd L. F. Kiff. 1985. The parasitic cowbirds and their hosts. Proceedings of the Western Foundation of Western Vertebrate Zoology 2:225-304.

Gehlbach, F. R. 1987. Natural history sketches, densities, and biomass of breeding birds in evergreen forests of the Rio Grande, Texas, and Rio Corona, Tamaulipas, Mexico. Texas Journal of Science 39:241-251.

Goguen, C. B., D. R. Curson, And N. E. Mathews. 2011. Costs of multiple parasitism for an avian brood parasite, the Brownheaded Cowbird (Molothrus ater). Canadian Journal of Zoology 89:1237-1248.

Gorton, M. J. 2010. Bronzed Cowbird (Molothrus aeneus) habitat use and differential response to playback of host song. M.S. thesis, The University of Texas-Pan American, Edinburg, Texas. 
Grietf, P. M., and S. G. Sealy. 2000. Simulated host activity does not attract parasitism by Brown-headed Cowbirds (Molothrus ater). Bird Behavior 13:69-78.

Hatнсоск, C. R. 2000. Factors affecting reproductive success in hosts of the Bronzed Cowbird (Molothrus aeneus) in the Lower Rio Grande Valley, Texas. M.S. thesis, The University of TexasPan American, Edinburg, Texas.

HathCOCK, C. R., AND T. BRUSh. 2004. Breeding abundance and distribution of the Altamira oriole at Santa Ana National Wildlife Refuge, Texas. Southwestern Naturalist 49:33-38.

Hauber, M. E., H. E. Pearson, A. Reh, And A. Merges. 2002. Discrimination between host songs by brood parasitic Brownheaded Cowbirds (Molothrus ater). Animal Cognition 5:129137.

Hutto, R. L., S. M. Pletshet, and P. Hendricks. 1986. A fixed radius point count method for non-breeding and breeding season use. Auk 103:593-602.

Keller, G. A. 2000. Bird songs of the Lower Rio Grande Valley and Southwestern Texas. Cornell Laboratory of Ornithology, Ithaca, New York.

Manolis, T., AND A. CRuz. 2002. Mating and nest-searching behavior of Shiny Cowbirds associated with different host species in Trinidad and Tobago. Pages 155-165 in Studies in Trinidad and Tobago ornithology honoring Richard French (F. E. Hayes and S. A. Temple, editors). Department of Life Sciences, University of West Indies, Saint Augustine, Occasional Papers 11.

Marsico, M., and J. C. Reboreda. 2008. Differential reproductive success favors strong host preference in a highly specialized brood parasite. Proceedings of the Royal Society B 275:24992506.

Monk, S. G., AND T. BRush. 2007. Response of brood-parasitic bronzed cowbird to playback of the song of Audubon's oriole. Southwestern Naturalist 52:440-443.

Norman, R. F., AND R. J. Robertson. 1975. Nest-searching behavior of the Brown-headed Cowbird. Auk 92:610-611.

Payne, R. B., L. L. Payne, J. L. Woods, and M. D. Sorenson. 2000. Imprinting and the origin of parasite-host species associa- tions in brood parasitic indigo birds, Vidua chalybeata. Animal Behavior 59:69-81.

Peer, B. D., and S. G. Sealy. 1997. Laying time of the Bronzed Cowbird. Wilson Bulletin 11:137-139.

RothsteIn, S. I. 1990. A model system for co-evolution: avian brood parasitism. Annual Review of Ecology and Systematics 21:481-508.

Sealy, S. G. 1996. Evolution of host defenses against brood parasitism: implications of puncture-ejection by a small passerine. Auk 113:346-355.

SeALY, S. G., AND T. J. Underwood. 2004. Acceptors and rejectors of cowbird parasitism in the New World orioles (Icterus spp.). Ornitologia Neotropical 15:331-347.

Sealy, S. G., D. G. McMaster, and B. D. Peer. 2002. Tactics of obligate brood parasites to secure suitable incubators. Pages 254-269 in D. C. Deeming (editor). Avian incubation: behavior, environment and evolution. Oxford University Press, Oxford, England.

Sealy S. G., J. E. Sanchez, R. G. Campos, and M. Marin. 1997. Bronzed Cowbird hosts: new records, trends in host use, and cost of parasitism. Ornitologia Neotropical 8:175-184.

Smith, A. P. 1912. Strange actions of a Red-eyed Cowbird. Auk 29:244.

SPSS Software, v. 17.0.2007. SPSS Inc., Chicago, Illinois.

Strausberger, B. M. 1998. Evident nest-searching behavior of female Brown-headed Cowbirds while attended by males. Wilson Bulletin 110:133-136.

Strausberger, B. M., And M. V. Ashley. 2003. Breeding biology of brood-parasitic Brown-headed Cowbirds. Auk 120:433445.

Thompson, C. F., And B. M. Gottrried. 1981. Nest discovery and selection by Brown-headed Cowbirds. Condor 83:268-269.

Werner, S. M., S. J. HeJL, And T. Brush. 2007. Breeding ecology of the Altamira Oriole in the Lower Rio Grande Valley, Texas. Condor 109:907-919.

Submitted 9 September 2013.

Acceptance recommended by Associate Editor, Eddie K. Lyons, 16 June 2014. 
Reproduced with permission of the copyright owner. Further reproduction prohibited without permission. 